Carey, M. (2018) 'Some limits and political implications of participation within health and social care for older adults’ Ageing and Society 


\title{
Some limits and political implications of participation within health and social care for older adults
}

\begin{abstract}
:
This paper critically examines service user -participation and involvement for older adults. It concentrates upon research and community-led engagement for older people, and maintains that despite extensive support and expansion, participation offers a complex form of governance and ideological control, as well as a means by which local governments and some welfare professions_seek to legitimise or extend their activities. Some of the paradoxes of participation are discussed, including tensions that persist between rhetorical claims of empowerment, active citizenship and democratic engagement on one hand, despite tendencies towards risk-aversion, welfare retrenchment and participant ambivalence on the other. The paper also highlights practical problems in relation to participative research and community involvement, and questions arguments that participation may challenge the authority of welfare professionals. Critical theory is drawn upon to contextualise the role of participative narratives within wider welfare, including its role in moving debate away from ownership or redistribution while masking and validating policy related goals which can counter many older people’s needs. Tension is also noted between participation projects represented as resource to support ageing identities as opposed to those representing technologies for social regulation and conformity.-
\end{abstract}

Keywords: participation; ideology; risk-aversion; empowerment; community 


\section{Some limits and political implications of participation within health and social care for older adults}

\section{Introduction}

Since the 1980s, there has been a continued growth in public and citizen participation or coproduction as part of more 'holistic', engaged and user-friendly service provisions within welfare (Blair and Minkler, 2009; Ziegler and Scharf,2014). For example, Littlechild and colleagues (2015: 19) highlight the- surge in the proportion of projects within health and social care which have employed older people as co-researchers. Participation and active engagement now takes a wide variety of forms, including the involvement of proactive citizens in research, education and training, alongside self-support, physical activities, service planning, evaluation, community and even policy development (Carr, 2004; Beresford, 2016). Through such initiatives the- representation of ageing can provide a series of spaces in which identities can be legitimately performed and realised, while the promotion of 'active ageing' may -support a variety of traits relating to "well-being" or the management of chronic illness or disability (Barnes 2005; Jackson, 2006; Hafford-Letchfield, 2010). Active engagement through citizenship may also politically contest traditional notions of passivity, disengagement or apparent dependence upon welfare in older age, as well as help challenge the perspectives and gaze of paternalistic professionals such as social workers and medics (Williams, 2003; Martin, 2011). Such outcomes are perhaps crucial at a time of extensive welfare retrenchment and austerity (Ziegler and Scharf, 2014). Among others, Barnes (2005: 246) has championed the great potential of older people 'having a say about services and policies', yet concedes that it is less clear how much influence such involvement or consultations are having, or whether 'real differences are being achieved'. 
Some sceptics, however, question the political and ethical implications of numerous participatory projects which exist for increasingly diverse groups of older people. For example $_{2}$ for research ${ }_{2}$ Ray (2007) has highlighted the differences in power which often remain between knowledge-rich researchers and older people who engage as 'lay experts'. Taylor (2005: 601-609) queries the democratising role of 'stakeholder participation', within which clashes of competing stakeholder interests may take place leading to projects quickly becoming more about the 'legitimisation of new forms of governance'. Scourfield (2007) has also raised questions about greater expectations now being placed on many older people who come to the attention of social services. Embedded within any discursive rhetoric around empowerment or participation is a tendency to shift responsibilities from the state to the individual regardless of needs. This includes that seemingly more active citizens are judged by professionals according to their capacity to become autonomous, self-managing or enterprising, whatever of the context in which needs are measured or assessed.

This paper aims to offer a critical overview of the politics of participation and involvement in relation to older people. It concentrates on health and social care provision within England and argues that participation in all its various guises offers a powerful yet paradoxical ideological means through which governments and welfare professions are able to legitimise their activities and, potentially, maintain types of domination and control. Some of the paradoxes of participation are noted, including relatively common practical difficulties attached to maintaining interest from service users or patients, as well as the possibility that some users or professionals may benefit from engagement activities for personal reasons, despite the limitations of broader projects. Despite elements of support (for example, Blair and Minkler, 2009; Littlechild et al, 2015), it is concluded that participation offers both a 
resource to aid circumscribed engagement as well a complex and diverse form of ideological governance which can_be more exploitative for older adults than other social groups.

The paper is in four parts. First,_a number of practical problems are noted for both participation research and community involvement, not least struggles to achieve interest in or ability to cope with projects by participants. Second, participation is placed into a political context, including tensions generated by a need to promote engagement alongside associated problems of governance and the ongoing retrenchment of welfare provisions. Third, arguments that participation may challenge the authority of professionals and forms of 'top down' governance are questioned. Indeed ${ }_{2}$ it is proposed that participation is -more likely to validate or even extend professional power. Finally, some of the ideological components of participation technologies are emphasised, including their capacity to represent an empowering resource despite often fulfilling objectives which can undermine ageing identities and needs.

\section{Practical problems with participation}

Since the 1980s -an abundance of government policies including from within the European Community have asserted a 'paradigmatic shift' by promoting the engagement and active citizenship of older adults within public services (Hafford-Letchford and Formosa, 2016). Advocates highlight that if adequately supported, participation can provide a foundation upon which to change and improve welfare services to meet- more diverse needs, as well as better integrate disenfranchised social groups. Such polices reflect a changed understanding of citizenship, one that is seemingly more engaged yet also- demanding; and from a neo-liberal perspective, eager to promote autonomy and enterprise (Higgs, 1997; Scourfield, 2007).

Scepticism by some older people of traditional authority figures such as welfare professionals - and their apparent tendency to dominate decision making, or largely discount lay and 
experiential knowledge - has again had influence (Beresford, 2016). Also, greater participation can offer a meaningful response to criticisms that many public services within democracies are no longer receptive to an increasingly knowledgeable and diverse range of welfare consumers, who now have more complex and fluid needs (Barnes, 2005: 246-247). Ziegler and Scharf (2014: 160), for example, detail the relative success of the Community Action in Later Life - Manchester Engagement (CALL-ME) project, which sought to utilise action research as a catalyst to extend opportunities for older people to participate more in local area-based activities (art groups, exercise classes, and so forth). They highlight evidence of active participation by many members nine months after the project began ${ }_{2}$ yet accept that any 'small victories' achieved should be 'viewed within the broader socio-political context of welfare state retrenchment' alongside the 'politicisation of citizen engagement in participants' residential communities’.

However, one immediate concern remains the number of practical problems recognised in most forms of participation and active citizenship. For example, when looking at more general forms of participation research, Littlechild et al (2015: 20) highlight difficulties faced in attempts to accurately quantify and evaluate positive impact (especially in the long-term). This may be associated with the limited resources available within research project budgets to achieve more ambitious aims, or that such attempts if pursued may undermine the core objectives of a project. There are also difficulties attached in accurately isolating and quantifying the rather nebulous concept of 'impact' within research. Subsequently many research projects have tended to instead focus on the 'benefits' of participation to those who participated in the research, as opposed to capturing the positive impact or drawbacks of user involvement in attempts to meet research questions or outcomes, or difficulties faced by participant co-researchers (see, also, Bartlett et al, 2015; Stevenson and Taylor, 2017). Participative research may also often tend to be 'timely and costly'. For example, developing 
good links with local stakeholders and communities will almost certainly benefit any project, yet as Brett (2014: 58) reflects, this is likely to be 'difficult within the time limitations of [any] study'. Further problems may emerge due to lay participants of all persuasion needing to undertake any necessary training, or any personal or health problems faced during the course of a project. Maintaining interest throughout a project may- again be a challenge beyond any initial eagerness, and conflicting available time-scales between researchers and participants can cause difficulties. Brett (2014: 59)- notes additional potential problems relating to- maintaining confidentiality throughout a study, whilst Ray (2007) has underlined that 'fourth agers' are often ignored as viable participants despite representing the bulk of clients accessing health and social care services. Potential power struggles_may transpire between participants, or participants and researchers, yet these may be underplayed by researchers eager to validate their findings.

Clough and colleagues (2006) undertook a participative research project for the Joseph Rowntree Foundation which included twenty--two older people acting as 'student researchers'. This impressive long-term study included 189 in-depth interviews carried out by older adult researchers themselves. The study aimed to examine the benefits and challenges of involving older people in qualitative research, especially that which might influence service quality and social policy. Whilst offering helpful guidance for future participation research and noting a range of benefits to co-researchers, the project also recounted a number of practical pitfalls which emerged throughout the project. These included difficulties involving the recruitment and retention of researchers alongside meeting the many training needs of co-researchers. Student co-researchers also faced difficulties completing core research activities such as undertaking a literature review or setting research objectives and undertaking interviews. Indeed, the writing of a final report caused numerous delays, and 
eventually one of the senior academics completed this task on behalf of the student researchers. As the principal investigator and academic noted in the final report:

The writing of this report has been a struggle precisely because of our attempts to collaborate. We did try to prepare for the task well in advance [yet] ...eleven months after that [first] meeting we are still working at the task...The writing of the report has been richly rewarding and yet frustrating. I hoped that the Older People Researching Social Issues members would either lead in organising or writing, or would complete whole chapters once we agreed a framework. Neither has happened. (Clough et al, 2006: 15-18).

_A tendency for participants from educated, white and middle-class backgrounds to be over represented remains a recurring theme in many welfare projects (see also Morrow and Richards, 1996; Grover, 2004; Bacon, 2015). In addition, navigation through often bureaucratic and sometimes onerous research ethics committees may prove more challenging if involving co-researchers, especially if they are identified as being "vulnerable”. Shaw (2005: 843-45) drew from challenges encountered in his social care related research, particularly with people from diverse backgrounds who_have encountered 'problem experiences’ relating to poverty, ageing, homelessness, mental health problems, and so forth. The author argues that key research tasks such as recruiting participants, gaining access, data collection or analysis can be regularly jeopardised because co-researchers may be more transient or less likely to be in stable employment or relationships. Due to past stresses or structural disadvantage some marginalised groups may also be more likely to articulate strong emotions, exaggerate or lie during conversations; or defy traditional middle-class norms and rules. Tensions may also persist between requirements for basic levels of cultural capital to 
complete core tasks, set against recurring political demands to promote engagement. Also, participants in some other studies have at times felt marginalised or isolated, including with regard to hearing their viewpoints, or are assumed to lack knowledge or not be taken seriously by professional researchers (Ong and Hooper, 2003; Hodgson and Canvin, 2005; Brett et al, 2010; Brett et al, 2014: 65).

Community_-based participation can again generate a similar variety of practical (and political) problems. Fenwick and McMillan (2012), for example, present a critical overview of New Labour's eagerness to promote a consumer-led brand of collaboration and community engagement in Britain for active citizens. They nevertheless detail a prescriptive, centrally controlled yet largely inconsistent form of public participation built upon earlier Conservative party initiatives. As well as a lack of clarity regarding the role and purpose of community involvement (beyond seemingly relentless rhetoric), limited evidence has persisted to support the claim that civic engagement increases the quality of provisions in local areas. Furthermore, and perhaps consequentially, there still remains little evidence to support the assumption often stressed by Governments that a high proportion of local people wish to participate in local activities or projects._Drawing upon empirical studies, such as by Lowndes et al. (1998) and Andrews et al (2008), the authors highlight the scepticism felt by many local people towards perpetual drives to encourage people to engage locally. This was especially the case when initiatives were led by local government:

There seems, from this, to be little evidence of an overwhelming groundswell of people wishing to participate. Even more interesting were the reasons given for not participating, including "overwhelmingly negative views of the council — its 
services, its officers, its members"; lack of information; typical lack of council response and, tellingly, the belief that it’s not for "people like me.”

One of the key policy areas to emerge in recent years which embraces the principles of coproduction remains personalisation (personal budgets, self-assessments, direct payments, and so forth) as part of adult social care provision within community settings. This principle policy initiative is linked to various community care policy reforms central to all governments in Britain since the 1990s. It is therefore welded ideologically to policies that have included the privatisation and fragmentation of social care, significantly reduced financial provisions and the related rationing of care services, set alongside the relative demise of preventative and therapeutic social work support (Lymbery, 2010). Despite its aggressive promotion from central government, available evidence of positive long-term engagement for older people remains far from convincing. For example, participation tends to be low among most older people requiring care (assuming funding is agreed), and,_many clients initially willing to engage tend to struggle to organise their own care, especially people with higher level needs (Gilbert and Powell, 2012; Woolham and Benton, 2013). Some studies have also noted that physically frail older people feel uncomfortable about complaining about such support if available, despite the principal of active consultation being central to the concept of personalisation. However, Ray (2014: 161) adds that actively engaging with such policies (regardless of circumstance) is now considered a 'moral duty', and that older people are 'otherwise considered to be 'unproductive' and 'burdensome”.

\section{Participation, engagement and governance}

The growth of participation as political force due in part to service user pressures and needs has had other influences. In analyzing the example of Britain during the immediate post-war 
years, Cowden and Singh (2007) reiterate contradictory dynamics at play in the development of user involvement within health and social care. These include that the traditional Welfare State was built upon overlapping and negotiated ideological positions within which different relations between social actors formed. As Gail Lewis (1998) had shown, international, political and economic pressures and relations_led to the idea that the post-war Welfare State was based on assumptions of entitlements. Many such assumptions - including those held by professionals, politicians and others - were often built upon a range of_implicit prejudices and myths. Such slants incorporated false understandings of class, gender, ethnicity, ageing or disability, and included the inferior and dependent status of women and older people. The eventual rise and influence of New Social Movements which included greater calls for democratic participation suggested that any prejudicial assumptions of entitlements were increasingly misplaced or even redundant.

Yet criticism of welfare provisions or professional insensitivity felt by service users ran in tandem with anxieties about the international decline of Britain articulated by the New Right, in particular the Conservative Party and various right-wing think tanks. Trade Union militancy and excess welfare provisions were identified as key themes which had influenced British decline (Drakeford, 2000; Clarke, 2004). Calls for more engagement by users remained embedded with paradoxical political influences and pressures that included a need to seemingly reorganize outmoded public services, generate economic efficiencies, promote an objective 'evidence base' of service impact, and centralize state governance whilst stimulating competition, choice, privatization, civic engagement and responsibilities (Cowden and Singh, 2007: 6-9). As Fenwick and McMillan (2012) add, the participation of disparate service users, patients and engagement of wider 'communities' has been carefully cultivated alongside the promotion of the free market, reduction of welfare services and more 
cynical assumptions held by elites about local communities: 'This attempt to move local public services towards a market model envisaged society as a collection of atomized individuals privately “consuming” services, empowered by the existence of competition and by the ostensible growth of choice' (Fenwick and McMillan, 2012: 368). Ironically greater 'democratic' engagement with welfare services has assisted their gradual withdrawal as part of a wider neoliberal ideological discourse. As pervasive hegemony, such reforms have also shifted attention away from possible aspirations geared towards material redistribution and increased ownership to instead privilege limited models of market-based participation.

Participation and social integration again remained core drivers of New Labour's politically malleable reinterpretation of 'social exclusion'. Levitas (2005: 178) argues that this revised political construct draws significantly from Durkheim, especially its wide appeal to social integration, solidarity and social cohesion. By avoiding any propensity to accept wider structural forms of disadvantage or inequality, responsibility and blame has instead been placed upon those who fail to participate, such as by seemingly generating their own sense of anomie. Here the seemingly emancipatory concept of 'empowerment' first initiated politically by the left was reconceptualised to embrace consumerism and neo-liberal interpretations of competition, open markets and increased private sector provision, alongside communitycentred_support and autonomy. Crucial as part of this reform agenda remained the promotion of participation not only at a local level but within employment and the labour market, as well as local communities such as through the active engagement of older people in voluntary work.

In analysing an increased role for numerous independent service providers within expanding markets of care since the 1980s, Clarke (2004) highlights the immediate problems 
of governance for the state. In particular, concerns persist of how a more dispersed and fragmented state that includes a myriad of independent service providers might maintain political control and stability at a distance? Part of the solution has come with the rapid expansion of audit and service evaluation within an increasingly 'hollowed out' state which creates networks for shaping and delivering public policy. Yet any diminished state must also look to find different forms of 'community-based governance' (Taylor, 2005: 604). Cruickshank (1999: 101), for example, argues that there has been a long tradition of liberal states seeking to actively produce empowered citizens, who are able to govern themselves and rely less upon the state. Citizens are encouraged and stimulated in person by professionals and through micro-policies to be more independent, such as through small-scale initiatives and social mobilisation programmes that seemingly reform and instill new attitudes and responsibilities through persuasive 'technologies of empowerment and citizenship'. Regarding ambitious democratic participation projects, such ‘tutelary power’ assimilates with outward forms of political freedom so that it is 'society at large, not a class or a tyrant, placing citizens in chains'.

One apparent new approach for older people which fits with a more dispersed model of local governance and active engagement remains asset-based care. This new means of support which embodies core elements of self-governance is advocated by the Local Government Association (LGA, 2012: 8-10). It claims a 'shift from using a deficit-based approach’ utilised by professionals including social workers, community nurses and others, which tend to focus upon meeting 'deficiencies and needs in the community'. Deficit-based approaches remain philosophically embedded within the traditional Welfare State, and are built around expertise, dependence and preconceived assumptions of entitlements. The LGA recognises these values as disempowering to customers, whilst encouraging professionals to become 
fixated on social problems and too eagerly seeking to 'provide services to users'. Asset-based approaches instead emphasise a collective and community-based approach to older people, and aim to utilise support 'mapping systems' and networks that identify strengths, and the generation of new ideas among community groups and collectives.

Asset-based approaches nevertheless embody underlying tensions. For example, they promote civic engagement and minimal state support but ignore that many social collectives of the distant past have either shrunk or largely disappeared. Communities have become smaller, more fragmented and, not uncommonly, exclusionary. Social groups often form around 'homophily', or the tendency to gather around people with similar characteristics such as shared interests or lifestyles, beliefs, ethnicity, social class or status (Jordan with Jordan (2000). Indeed, recent government policy documents in England which seek to reform welfare provisions and sectors not untypically depict 'community' in an over simplistic way, preferring, for example, a largely abstract hegemonic construct which is homogenous and crudely depicted as a resource to mine for 'social capital' and 'assets'. Here the many ways by which communities vary 'by locality, interest, history, class, economy, ethnicity or culture' tends to be bypassed, alongside any 'inequalities in their resources’ (Whittington, 2016: 14). In their critique of the United Kingdom Government policy of asset-based social care, Daly and Westwood (2017: 11) highlight numerous policy advocates denial of established policies and professional practices which already contain an asset-based dimension. For example, adult social workers or General Practitioners and their relative engagement in local communities. This tenet of a flawed thesis sits alongside numerous exaggerated claims made about what asset-based care can achieve, especially in the long-term. This is despite a lack of any substantive evidence-base provided to support this policy, alongside its lack of 'meaningful engagement with macro issues'. The authors conclude that such factors risk the 
promotion of an overtly ambitious participation-centred policy initiative targeted at older people which nevertheless neglects the full extent of unmet need, and appears 'unrealistic' in its assessment 'of the volume of untapped resources that exist and can be mobilised for social care'.

\section{Professional power, risk-aversion and minimal interventions}

As detailed earlier part of the validation by Governments for promoting greater participation and user involvement has remained an assumption that welfare professions were previously unaccountable and maintained significant power over patients or service users. This point was articulated by advocates on both the political left and right, alongside many users of public services. Swain and colleagues (2003: 133), for example, argue that such 'experts' have been perceived by many clients as ‘controlling, distant, privileged, self-interested, domineering and the gatekeepers of scarce resources.' One of the risks that greater participation paradoxically generates is that such experts may be able to further validate their roles, and therefore consolidate or even increase any monopoly of power, by promoting through participation their key roles as more democratic, shared, open or altruistic.

Whilst additional neo-liberal reforms have curtailed much of the discretion of welfare professionals such as social workers - especially through increased levels of accountability including targets, bureaucracy and audit alongside more acute forms of managerialism (Webb, 2006; Lymbery, 2010) - not all commentators remain convinced that their power and discretion over clients has been minimised. Furedi (2004; 2011), for example, contests that reliance upon the power of many 'helping professionals' such as counsellors, mentors and social workers has increased since the 1960s. This associated paradigm shift relates as much to cultural and social rather than 'top down' political changes such as those instigated by market-led reforms. Influences include the relative breakdown of informal support networks 
previously provided within local communities and the extended family, or amongst religious and large-scale employment-based associations including trade unions. In tandem there has emerged an assumption that once taken for granted experiences or events within the life course such as child-rearing, bereavement,- frailty or stress now requires professional interventions or diagnosis. A 'diminished self' has subsequently emerged which relies ever more upon the viewpoints and interventions of experts, who have filled a vacuum generated in part by the relative atomisation of society and demise of informal support or care. Within this discursive terrain, participation events or projects may offer another means by which the expert can find reasons to emphasise the importance of their knowledge base or skills within seemingly democratic fields that embody partnership, co-production, empathy and empowerment. Inevitably an ageing population is likely to offer new opportunities for therapeutic interventions which encourage greater learning, reflexivity $y_{2}$ engagement and therapeutic support for the diminished self.

Begum (2006: 20-21) critically analysed the participation of black service users (including older people) within social work. She discovered that just as participation has expanded as priority since the 1980s it has also disproportionately curbed the proportion of ethnic minority users directly involved as co-producers during this time (see also Hernandez et al, 2010). Alongside prejudices felt towards black service users on behalf of a number of social work staff, Begum discovered a tendency by some policy makers or professionals to prefer approaching fellow black professionals or community leaders -sometime referred to as 'substitute service users' - rather than black families about their opinions or experiences. Begum notes, however, that such professionals may not have direct personal experience of using social care services, or of being assessed and evaluated, and are themselves 'not immune to holding stereotypical views of service users and what they need'. 
Cowden and Singh (2007) add that participation within welfare sectors now remains an important part of political governance, a key part of which has included the expansion of 'professional users' and 'expert consultants', -some of whom may have a limited grasp of the issues affecting minority groups. In such instances critiques of professional practices, support services or policy by older service users or care givers may be marginalised, or disappear as priority, whilst the agendas of professionals and managers remain or are strengthened through the influence of a persuasive ‘co-production’ hegemony. As Cowden and Singh (2007: 19) note:

The [participative] consensual approach employed here elides and obscures issues of power relations, which become reduced to consumer notions of 'choice' and managerial 'listening', the truth of which are exemplified by the meeting situation in which the 'pause button' is subtly deployed whenever a service user speaks.

Whilst detailing the increasing dominance of established Charities or Voluntary Sector organizations (such as Age UK) in service provision, Vincent (1999: 93-95) argues that participatory processes may aspire to improve service delivery yet are unlikely to help 'set a political agenda' or 'change power structures'. Vincent also notes that such 'third sector' providers can relatively easily misrepresent the opinions of increasingly diverse groups of older people. For example, such ever more dominant service providers are regularly contacted by media outlets to voice their opinions on new policies or legislation effecting older people, yet tend to be staffed by a high proportion of highly educated welfare professionals who may be more inclined to 'reach an accommodation with existing power structures in a manner which does not disadvantage their own careers'.

Hodgson and Canvin (2005: 54) again question the authenticity of using older participants within health-care research projects, and argue instead that this tradition stands as much as 
political process which fortifies established institutions and professional careers. One key problem remains that patient knowledge bases or experiences lack the esoteric, technical and scientific detail or cultural capital often gained prior to, and then throughout, the course of long-term formal medical training. Typically $y_{2}$ such tacit knowledge, alongside an awareness of appropriate social skills, remains crucial for survival in the fiercely competitive arenas of medical or health care research and practice. In such intense and often hostile discursive arenas the patient as user is likely to quickly lose confidence or become perplexed if clumsily inserted into ritualistic hegemonic projects that appear overtly complex, or which seem to lack direct relevance.

Despite the possible legitimacy offered by participation, and occasional invitations to engage in a range of projects, such initiatives have not untypically proceeded alongside the withdrawal of direct interventions and services, which often remain limited and fragmented. For example, in emphasising neo-liberal inspired welfare retrenchment, Jones and Novak (1999) offer a materialist stance to detail the 'abandonment' of core community groups such as older people by dominant political classes. Webb (2006: 150) adds that risk-aversion and independence are increasingly promoted from afar by coordinating welfare recipients to 'take responsibility for [their] actions and choices’. Despite greater consultation for some, Higgs (1997) points to diminished notions of citizenship for many older people, alongside the increased role of surveillance and the identifying or measuring of risk undertaken by welfare professionals, rather than provision of support.

\section{Participation as ideology and resource}

The benefit of participation within research or community settings alongside different types of health and social care provision for older people chime with the principles of active agency 
and co-production and appear to challenge traditional notions of disengagement or dependency. Important critiques nevertheless persist that question the rationale of engagement, active ageing and participation. Cooke and Kotari (2001), for example, raise concerns that a seemingly global drive to encourage participative democracy may further help to legitimise and empower dominant groups and nation-states, and lead to unrepresentative and partisan decision-making. In particular, strong stances articulated by the better educated, privileged, or more vocal 'professional service user' may proliferate. Alongside other forms of governance or surveillance,_participation can_also offer a vital platform upon which professional groups or ruling elites_gain legitimacy and control within increasingly fragmented welfare sectors. Moreover, ${ }_{2}$ participation may be used as a low-cost ideological device by other agencies - including local or national governments - to conceal hidden agendas or disparities in power. Clarke (2004: 33), for example, has highlighted the links between active citizenship and neoliberal desires ‘to produce “responsible subjects”'. Earlier Harrison and Mort (1998) articulated the use of largely superficial public consultation and user involvement events as ‘social technologies of legitimation’ to mask the wide-ranging expansion of quasi-markets within the National Health Service and social care since the 1980s. It has been argued as part of this paper that such initiatives carry significant practical problems and link also to ideas of a 'diminished self' and reduced understanding of citizenship.

Theoretically, in Althusser’s (1971) interpretation, narrative constructs such as ‘active ageing’ or 'service user participation' can be understood as utilising an ideological device built around an 'imaginary story' in which clients are offered more choice and democratic engagement previously denied by dominant professionals, paternalistic state bureaucracies and institutions throughout the 1970s and 1980s. Participation can be additionally recognised 
as reliant upon strong narratives that relentlessly cast a positive interpretation of involvement: for example, by projecting a robust slant given to the benefits attached to independent care, autonomy and community cohesion, whatever the many materialist or power-based obstacles to such aspirations or claims. Agency is subsequently enacted and empowered yet correspondingly compromised through a distorted relationship with the material conditions of a market-led state. As well as highlight the 'relative independence' of ideology - and note the material basis of its formation and application = Althusser (1971, pp 135-141, pp 155-165; 2003) also drew upon Lacan's (1977) proposition of a 'symbolic order' to highlight the central role of language in generating imaginary forms of recognition and achievement as part of established semiological systems. Here, notions of 'active ageing', 'partnership', 'empowerment' or 'co-production' appear to help older 'users' to gain recognition, manage identities and experience a sense of accomplishment, however restricted such involvement may prove in the long-term as part of relatively brief or superficial projects. Despite these limitations, for many older people during times of welfare change, instability and retreat, such projects are likely to offer an increasingly rare resource upon which to draw. Similarly, for welfare professionals facing difficulties in relation to work intensification, limited resources or brief spurts of time to engage meaningfully with users - comparable motives to accept new resources such as personal budgets or participatory action research projects may persist. Whatever any drawbacks or political consequences, participation in different fields therefore may be justified in order to help cope with difficult truths, a challenging world that seemingly lacks concrete meaning or because it initially fulfils a short-term purpose. As Kemshall (2010: 1249) notes in her critical account, engagement is rarely rational in an economic sense, or based on simple decisions made between new opportunities and risks. For “situated” social actors’_decisions to engage are more likely ‘negotiated, collective and contingent on contextually based' experiences. . 
At the level of agency whilst potentially elevating 'empowerment', self-esteem, influence, or some degrees of choice for a few, participation also reflects a different concept of ‘citizenship’ to that which traditionally operated under the welfare state. In the latter ethical notions of justice inculcating entitlements were emphasised (Rawls 1996); whereas participation endeavours such as personalisation or asset-based care understand support more as promoting capacities for autonomy and self-care. Research evidence within social care suggests that such claims are regularly compromised for older people by policies that limit the provision of direct care and professional support (Ferguson, 2007; Kemshall, 2010; Ray, 2014; among others). Similar deficits and risks have again been highlighted within health care. Tutton (2005: 143), for example, has noted that although policy documents in the United Kingdom emphasise a need for patient involvement 'at all levels within the National Health Service', research into such involvement suggests that staff 'still retain a controlling position in staff-patients interactions' and 'older people seem to be particularly vulnerable in this area'. In relation, Scott-Samuel and Smith (2015: 2-3) highlight neo-liberal governments and politicians continued attraction to 'relatively low-cost policy options' which provide short-term solutions without having to 'substantially engage with power inequalities' or the redistribution of material and cultural assets (see also, Levitas, 2013). Participation and coproduction in all its guises fits perfectly with this political ideal, in that it pushes responsibilities downwards, avoids having to meaningfully confront material inequalities or power differences, but offers opportunities for older subjects to play some part in welfare activities which seemingly empower whilst offering recognition. Meaningful participation is likely to be more about shared ownership and control rather than tokenistic engagement, and it is perhaps these ideals which a more critical gerontology might look to rekindle as an ideal. As part of such debates we might query some of the ulterior agendas that motivate 
coproduction, and the ethical implications - including of possible exploitation - this may carry. For example, the more recent popularity of involving people with dementia in funded research projects (Bartlett et al, 2015; Stevenson and Taylor, 2017) carries a range of ethical dilemmas and possible risks, yet these may diminish as priority due to institutional pressures or personal career aspirations_since participation can significantly help researchers in acquiring otherwise highly competitive research grants. For such reasons and others stated, many core facets of participation - including as both dominant ideology and resource - might be treated with a healthy degree of scepticism by older people and welfare professionals.

\section{References}

Althusser, L. (1971) Essays on Ideology, London: Verso.

Althusser, L. (2003) The Humanist Controversy and Other Writings. London: Verso.

Andrews, R., R. Cowell, \& J. Downe. (2008). Support for active citizenship and public service performance: An empirical analysis of English local authorities. Policy and Politics, 36 (2), 225-243.

Author (2010)

Author (2013)

Author (2015) 
Bacon, J. (2015) An Exploration of Child Voice and its Use in Care Planning Unpublished PhD, University of Chester.

Barnes, M. (2005) 'The same old process? Older people, participation and deliberation' Ageing and Society 25(2): 245-259.

Barnes, M. and Prior, D. (2009) (eds) Subversive Citizens: Power, Agency and Resistance in Public Services. Bristol: Policy Press.

Bartlett R., Hick C., Houston A., Gardiner L., Wallace D. (2015) Privileging place:

Reflections on involving people with dementia in a residency. Dementia: The International Journal of Social Research and Practice 14(6): 788-799.

Begum, N. (2006) Doing It for Themselves: Participation and Black and Ethnic Minority Service Users: Participation Report 14 London, Social Care Institute for Excellence.

Beresford, P. (2016) All Our Welfare Bristol, Policy Press.

Blair, T. and Minkler, M.(2009) 'Participatory Action Research with Older Adults: Key principles in practice'The Gerontologist 49(5): 651-662.

Brett, J., Staniszewska, S., Mockford, C., Seers, K., Herron-Marx, S., and Bayliss, H. (2010) A systematic review of the conceptualization, measurement, impact and outcomes of patients 
and public involvement in health and social care research London, UK Clinical Research Collaboration

Brett, J. (2014) 'Mapping the impact of patient and public involvement on health and social care research: a systematic review'. Health Expect 17(5): 637-650.

Carr, S. (2004) Has Service User Participation Made a Difference to Social Care Services? Position Paper 3 London, Social Care Institute for Excellence.

Clarke, J. (2004), 'Dissolving the public realm? The logics and limits of neo-liberalism', Journal of Social Policy, 33: 1, 27-48.

Clough, R., Green, A., Hawkes, B., Raymond, G., and Bright, L. (2006) Older people as researchers: Evaluating a participative project York, Joseph Rowntree Foundation

Cooke, B. and Kathari, U. (eds) (2001) Participation - The New Tyranny? London: Zed Books.

Cowden, S. and Singh, G. (2007) 'The "User": Friend, Foe or Fetish? A Critical Exploration of User Involvement in Health and Social Care', Critical Social Policy 27(1): 5-23.

Cruickshank, B. (1999) The Will to Empower: Democratic Citizens and Other Subjects London: Cornell University Press. 
Daly, M., and Westwood, S. (2017) 'Asset-based approaches, older people and social care: an analysis and critique' Ageing and Society Advanced Online: $28^{\text {th }}$ March

Drakeford, M. (2000) Privatisation and Social Policy Harlow, Pearson.

Fenwick, J. and McMillan, J. (2012) 'Public participation and public service modernisation: Learning from New Labour?' International Journal of Public Administration 35 (6): 367-378.

Ferguson, I. (2007) 'Increasing User Choice or Privitizing Risk? The Antimonies of Personalisation' British Journal of Social Work 37 (3): 387-403.

Furedi, F. (2004).Therapy Culture: Cultivating Vulnerability in an Uncertain Age. London: Continuum.

Furedi, F. (2011).On Tolerance: A Defence of Moral Independence.London: Continuum.

Gilbert, T and Powell, J.L. (2012) 'The Place that Social Policy Plays in Shaping the Social Context of Older People' in Davies, M. (ed) Social Work with Adults Basingstoke, Palgrave Macmillan

Grover, S. (2004) "Why won't they listen to us? On giving power and voice to children participating in social research." Childhood 11(1): 81-93.

Hafford-Letchford, P. (2010) 'The Age of Oppertunity? Revisiting Assumptions about the LifeLong Learning Oppertunities of Older People Using Social Care Services' British Journal of Social Work 40: 496-512. 
Hafford-Letchford, P. and Formosa, M. (2016) 'Mind the gap! An exploration of the role of lifelong learning in promoting co-production and citizenship within social care for older people' European Journal for Research on the Education and Learning of Adults, Prepublished, 2016: $\mathrm{x}-\mathrm{xx}$

Harrison, S. and Mort, M. (1998)'Which Champions, Which People? Public and User Involvement in Health Care as a Technology of Legitimation' Social Policy and Administration 32 (1): 60-70.

Hernandez, L., Robson,P., Sampson, A.(2010) 'Towards Integrated Participation: Involving Seldom Heard Users of Social Care Services'. British Journal of Social Work 40 (3): 714-736.

Higgs, P. (1997) 'Citizenship Theory and Old Age: From Social Rights to Surveillance' in Jamieson, A., Harper, S., and Victor, C. (eds.) Critical Approaches to Ageing and Later Life Buckingham, Open University Press.

Hodge, S. (2005) 'Participation, discourse and power: A case study', Critical Social Policy 25(2): 164-179.

Hodgeson, P. and Canvin, K. (2005) 'Translating health policy into research practice' in Lowes, L. and Hulatt, I. (eds) Involving Service Users in Health and Social Care Research, London: Routledge. 
Jackson, S. (2006) 'Learning to live: The relationship between lifelong learning and lifelong illness', International Journal of Lifelong Education, 25(1): 51-73.

Jones, C. and Novak, T. (1999) Poverty, Welfare and the Disciplinary State London, Routledge.

Jordan, B. with Jordan, C. (2000) Social Work and the Third Way: Tough Love as Social Policy. London: Sage.

Kemshall, H. (2010) 'Risk rationalities in contemporary social work policy and practice', British Journal of Social Work, 40(4), pp. 1247-62.

Lacan, J. (1977) The four fundamental concepts of psychoanalysis. London: Hoghart Press.

Levitas, R. (2005) The Inclusive Society? Social Exclusion and New Labour $2^{\text {nd }}$ Ed Basingstoke, Palgrave MacMillan.

Levitas, R. (2013) Utopia as Method: The Imaginary Reconstitution of Society. Basingstoke, UK: Palgrave Macmillan

Lewis, G. (1998) 'Coming Apart at the Seams: The Crisis of the Welfare State', pp. 38-79 in G. Hughes and G. Lewis Unsettling Welfare: the Reconstruction of Social Policy. London: Routledge/Open University. 
Lloyd, E. (2010)'The individual in social care: The ethics of care and the 'personalisation agenda' in services for older people in England'Ethics and Social Welfare 4 (2): 188-200

Local Government Association (2012) Ageing well: An asset approach London, OPM Lowndes, V., \& H. Sullivan.(2008). 'How low can you go? Rationales and challenges for neighborhood governance'. Public Administration, 86 (1): 53-74.

Littlechild, R., Tanner, D., and Hall, K. (2015) 'Co-research with older people: Perspectives on impact' Qualitative Social Work 14 (1): 18-35.

Lymbery, M. (2010).'A New Vision for Adult Social Care? Continuities and Change in the Care of Older People'. Critical Social Policy, 30(1)

Martin, W. (2011) 'Visualizing Risk: Health, Gender and the Ageing Body' Critical Social Policy 32 (1): 51-68.

McLaughlin, H. (2006) 'Involving young service users as co-researchers: Possibilities, benefits and costs', British Journal of Social Work 36(8): 1395-1410.

Morgan, D.L. (1988) 'Age Differences in Social Network Participation'. Journal of Gerontology 43 (4):129-137 
Morrow, V., and Richards, M. (1996) 'The Ethics of Social Research with Children: An Overview' Children and Society 10 (2): 90-105

Ong, B.N., and Hooper, H.(2003) 'Involving Users in Low back pain research' Health Expectations 6: 332-341.

Rawls, J.(1996) Political Liberalism New York, Columbia University Press.

Ray, M. (2007) 'Readdressing the balance? The participation of older people in research' in Bernard, M., and Scharf, T. (eds) Critical Perspectives on Ageing Societies Bristol, Policy Press.

Ray, M. (2014) 'Critical Perspectives on Social Work with Older People' in Baars, J., Dohmen, J., Grenier, A., and Phillipson, C. Ageing, Meaning and Social Structure: Connecting Critical and Humanistic Gerontology Bristol, Bristol.

Rose N. (1996) The Death of the Social? Re-figuring the territory of government.Economy and Society, 25(3): 327-356.

Scott-Samuel, A., and Smith, K.E. (2015) 'Fantasy Paradigms of Health Inequalities: Utopian thinking?' Social Theory and Health advanced online publication: $1^{\text {st }}$ July

Shaw, V. N. (2005) 'Research with Participants in Problem Experience: Challenges and 
Strategies', Qualitative Health Research 15(6): 841-54.

Stevenson, M. And Taylor, B.J. (2017) 'Involving individuals as Dementia as Co-researchers in Analysis of Findings from a Qualitative Study' Dementia Online Access January 29th

Swain, J, French, S. and Cameron, C. (eds) (2003) Controversial Issues in a Disabling Society, Maidenhead: Oxford University Press.

Taylor, D. (2005) Governing through evidence: Participation and power in policy evaluation Journal of Social Policy 34 (4): 601-618.

Tutton, E.M.M. (2005) 'Patient participation on a ward for frail older people' Journal of Advanced Nursing 50 (2): 143-152.

Vincent, J.A. (1999) Politics, Power and Old Age Buckingham, Open University Press

Woolham, J., and Benton, C. (2013) 'The Costs and Benefits of Personal Budgets for Older People: Evidence from a Single Local Authority'. British Journal of Work 43 (8): 1472-1491.

Williams, S.J. (2003) Medicine and the Body. London: SAGE.

Webb, S.A. (2006) Social Work in a Risk Society Basingstoke, Palgrave MacMillan. 
Whittington, C. (2016) 'The promised liberation of Adult Social Work under England's 2014 Care Act: Genuine Prospect or False Prospectus?' British Journal of Social Work Advanced Access March 10th

Ziegler, F. and Scharf, T. (2014) 'Community based participatory action research: Opportunities and challenges for critical gerontology' in Baars, J., Dohmen, J., Grenier, A., and Phillipson, C. (eds) Ageing, Meaning and Social Structure: Connecting Critical and Humanistic Gerontology Bristol, Policy Press. 